\title{
Heraldické a epigrafické pamiatky domov v Spišskej Novej Vsi a ich pramenná hodnota pri identifikácii ich majitel’ov
}

aвstrakт: Autor príspevku sa na základe porovnania výsledkov vlastného archívneho výskumu majitelov domov historického centra Spišskej Novej Vsi v 18. a 19. storočí so stavebno-historickým výskumom Jana Muka (1981) a genealogickým výskumom Mártona Szluhu šlachty na Spiši (2013) pokúsil o identifikovanie heraldických a epigrafických pamiatok domov historického centra Spišskej Novej Vsi, ktoré vznikli v období od 17. storočia do začiatku 20. storočia.

SŁOWA KLuczowe: Slovensko, Spiš, Spišská Nová Ves, 17.-20. storočie, epigrafika, heraldika, majitelia meštianskych domov.

V súvislosti s tvorbou nových historických expozícií v Múzeu Spiša, ktoré prešlo v rokoch 2015-2016 komplexnou rekonštrukciou', sa jednou z výskumných priorít spoločenskovedného oddelenia stal stavebný vývoj mesta so zameraním na meštianske domy, ako aj vývin sociálnej štruktúry obyvatel'stva mesta v 18. a 19. storočí. V tom čase plnila Spišská Nová Ves významnú pozíciu v správnej štruktúre historického regiónu, kedže v rokoch 1774-1876 bola administratívnym centrom Provincie XVI spišských miest ${ }^{2}$. Prvým výstupom uvedenej výskumnej úlohy bolo napísanie štúdie Majitelia domov historického centra Spišskej

1 Prehladne o rekonštrukcii sídla múzea pozri M. Janovská, Z. Krempaská, Provinčný dom v Spišskej Novej Vsi. História - architektúra - múzeum, Spišská Nová Ves 2016.

2 M. Števík, Provinčný dom v Spišskej Novej Vsi a Provincia XVI spišských miest, Spišská Nová Ves 2016, s. 11-20. 
Novej Vsi v poslednej tretine 18. storočia, ktorá vyšla vo „Vlastivednom zborníku Spiš“ v roku $2016^{3}$. V spomínanej štúdii sa podarilo určit majitelov 108 domov historickej zástavby mesta z obdobia rokov 1773-1800. Kedže počas uplynulej štvrtiny tisícročia sa v Spišskej Novej Vsi uskutočňovali početné prestavby domov, súpisy a výruby daní Spišskej Novej Vsi z rokov $1773-1800^{4}$ nemohli byt jediným prameňom pre určenie vlastníkov predmetných objektov. Popri historických plánoch mesta z rokov $1783^{5}$ a $1869^{6}$ sa dôležitou súčastou výskumu, resp. jeho pramennej bázy stali heraldické a epigrafické pamiatky domov námestia (erby, znaky stavebníkov, meštianske znaky, nápisy), ktoré vo viacerých prípadoch overili správnost̉ určenia majitelov predmetných objektov v poslednej tretine 18. storočia. Heraldické a epigrafické pamiatky sa podarilo zistit z rokov 1631-1904, pričom tri štvrtiny z nich pochádzajú z 18. storočia. V nasledujúcej časti príspevku sa o nich v chronologickom poradí (od najstaršieho po najmladší) zmienime podrobnejšie.

1631 (Letná 59, il. 1)

Najstarší nápis sa podarilo zistit na dome na Letnej 59, ktorý má gotický pôvod ${ }^{7}$ V jeho dvorovej časti sa na kamennej doske nachádza renesančný nápis M.S H.L ANNO $16.31^{8}$. Na základe analógie s obdobným nápisom na dome na Letnej $51^{9}$ sa domnievame, že písmená M.S sú iniciály majitela predmetného domu a písmená H.L iniciály jeho manželky. Rok 1631 dokumentuje renesančnú

3 M. Števík, Majitelia domov historického centra Spišskej Novej Vsi v poslednej tretine 18. storočia, „Spiš. Vlastivedný zborník”, t. 8, 2016, s. 72-119.

4 Magyar Országos Levéltár, Budapest, Urbaria et conscriptiones, E 156 - a. - Fasc. 121. - No. 028 (1773); Spišský archív Levoča, Provincia xvi spišských miest, Súpisy a výruby daní, Spišská Nová Ves, i. č. 935 (1774/1775, 1775); i. č. 936 (1775/1776); i. č. 937 (1776/1777); i. č. 938 (1777/1778); i. č. 945 (1783/1784); i. č. 952 (1800/1801), i. č. 985 , b. r., nedatovaný a neidentifikovaný daňový súpis Spišskej Novej Vsi.

M. Števík, Geometrický plán vnútorných pozemkových majetkov Spišskej Novej Vsi z roku 1783 (Príspevok k počiatkom Provincie XVI spišských miest), „Spiš. Vlastivedný zborník”, t. 6, 2014, s. 73 i in.

6 Archív Geodetického a kartografického ústavu Bratislava. Podklad 1. katastrálneho mapovania Spišskej Novej Vsi z roku 1869 (dalej: AG, poklad 1, SNV 1869).

7 J. Muk, Spišská Nová Ves. Stavebně historický průzkum historického jádra města. Státní ústav pro rekonstrukci památkových měst a objektů v Praze, Praha 1981, strojopis, Letná 59.

8 M. Števík, Majitelia domov, s. 102.

9 Ibidem, s. 100. 
prestavbu objektu. V rokoch 1773-1775 je doložená ako vlastníčka tohto domu šlachtičná Dorothea Figutovszky, ktorej v tom čase patril aj dom na Zimnej $55^{10}$.

1640 (Letná 34, il. 2)

$\mathrm{V}$ jednom $\mathrm{z}$ architektonicky najhodnotnejších renesančných domov Spišskej Novej Vsi sa v dvorovej časti zachoval na kamennej (pieskovcovej) doske nápis: PAVLVS (?) ANNO DO(MINI). Podla Súpisu pamiatok z roku 1969 bol dom postavený $\mathrm{v}$ roku $1640^{11}$. V rokoch 1773-1784 tento dom vlastnila šlachtická rodina Szulovszky, ${ }^{12}$ v roku 1800 už vystupuje ako majetok šlachtica Michala Szontaga ${ }^{13}$. Jan Muk si pri stavebno-historickom prieskume všimol, že tento renesančný dom má neobvyklý trojtrakt ${ }^{14}$. $\mathrm{V}$ tejto súvislosti stojí za pozornost’ skutočnost', že zadná čast' objektu tvorila v roku 1800 samostatný dom s číslom 640, ktorého majitel'om bol Paul Windt ${ }^{15}$. S najväčšou pravdepodobnostou ide o príslušníka šlachtického rodu Windt, ktorý sa narodil v Spišskej Novej Vsi v roku 1745, prípadne o jeho syna Pavla ${ }^{16}$. V prednej časti spomínaného domu sa na prvom poschodí na kamennom portáli zachoval znak stavebníka s monogramom $G H^{17}\left(\right.$ il. 3). Kedže portál je renesančnýl ${ }^{18}$, znak zaznamenáva realizátora - murárskeho majstra renesančnej prestavby objektu v roku 1640. Je ale velmi pravdepodobné, že portál je v tejto polohe umiestnený sekundárne ${ }^{19}$.

1671 (Letná 33)

Na mieste starého vel'kého meštianskeho domu bola v roku 1936 vystavaná filiálka Pražskej banky. Svedčí o tom mozaikový erb Prahy na fasáde s textom: PRAHA MATKA MĚST, popri ktorom sa nachádza nápis: L. P. $1936^{20}$. Ivan

${ }^{10}$ Ibidem, s. 82, 100.

11 Súpis pamiatok na Slovensku, t. 3, red. A. Güntherová, Bratislava 1969, s. 152.

${ }_{12} \mathrm{O}$ šlachtickej rodine Szulovszky pozri bližšie M. Szluha, Szepes vármegye nemes családjai, Budapest 2013, s. 387.

${ }_{13}$ M. Števík, Majitelia domov, s. 92. O šlachticovi (lekárovi) Michalovi Szontagovi (17511825) pozri bližšie D. Szontagh, Iglói és zabari Szontagh nemzetség származási története és oklevelei, Pest 1864, s. 14, 16.

${ }^{14}$ J. Muk, op. cit., Letná 34.

${ }_{15}$ M. Števík, Majitelia domov, s. 92.

16 O šlachtickej rodine Windt pozri bližšie M. Szluha, op. cit., s. 433.

17 M. Števík, Majitelia domov, s. 75, 92.

${ }_{18}$ Za odbornú konzultáciu d’akujeme historičke umenia Mgr. Michaele Haviarovej.

19 Za upozornenie na uvedenú skutočnost' dakujeme historičke umenia Mgr. Michaele Haviarovej.

${ }^{20}$ Chalupecký I., Spišská Nová Ves a okolie, Košice 1971, s. 72. 
Chalupecký zaznamenal údaj o existencii mramorovej tabule v chodbe objektu, nad ktorou bol nápis: RENOVATVM 1671. Pod tabulou boli dva erby, ktoré zobrazovali na trojvrší stojacu holubicu s vetvičkou v zobáku. Pri tom bola majstrovská značka ${ }^{21}$. Predmetný dom vznikol počas rokov 1777-1783 spojením pôvodne dvoch samostatných domov. V poslednej tretine 18. storočia ho obývala šlachtická rodina Grünblath ${ }^{22}$. Erb rodiny Grünblath obsahuje čiernu kaňu $s$ roztvorenými krídlami, ktorá stojí na trojvrší a drží v zobáku olivovú ratolest ${ }^{23}$. Znamená to, že rodina Grünblath vlastnila dom na Letnej ulici už v 17. storočí a iniciovala jeho prestavbu, resp. obnovu v roku 1671.

1726 (Zimná 65, il. 4)

V dvorovej časti domu na Zimnej 50 sa nachádza sekundárne umiestnený meštiansky znak s iniciálami $i B$ a rokom $A(n n o) ~ 1726^{24}$. Tento objekt vznikol spojením dvoch samostatných domov, k čomu došlo po roku $1869^{25}$. Spomínaný znak sa nachádza na múre, ktorý bol súčastou priestoru (parcely), kde stál pôvodne samostatný dom so stredovekým základom ${ }^{26}$. V tomto dome bývala v roku 1773 šlachtičná Anna M. Szontagh ${ }^{27}$, v tom čase vdova (Vid. Benigny), ktorej prvým manželom bol Johann Benigni. Znamená to, že predmetný meštiansky znak dal v roku 1726 vyhotovit bud' Ján Benigny, manžel Anny M. Szontagh, alebo jeho otec. Druhá možnost̉ je pravdepodobnejšia. Uprostred znaku sa nachádza banícky symbol - skrížené banícke nástroje - kladivko a želiezko, z čoho vyplýva, že Ján Benigny sa venoval tažiarstvu, čo bola typická činnost̉ pre mnohých majitelov domov centra tohto baníckeho mesta ${ }^{28}$. Vznik znaku v danom období ozrejmil J. Muk. V súvislosti s iným domom v meste (na Letnej 40)

${ }^{21}$ Ibidem.

${ }_{22}$ M. Števík, Majitelia domov, s. 92.

${ }^{23}$ M. Szluha, op. cit., s. 129.

${ }^{24}$ M. Števík, Majitelia domov, s. 75, 114. Za upozornenie na uvedenú skutočnost’ dakujeme spišskonovoveskému autorovi literatúry faktu Jánovi Petríkovi.

${ }^{25} \mathrm{~V}$ roku 1869 sú oba objekty zakreslené ešte samostatne (AG, podklad 1, SNV 1869). Jan Muk predpokladal, že k spojeniu domov došlo v období klasicizmu (J. Muk, op. cit., Zimná 65), no stalo sa tak až neskôr, po roku 1869, resp. pred rokom 1914. Pozri: Archív Múzea Spiša, mapy, nr 337 H, Igló szepesvármegyei rendezett tanácsú királyi korona és bányaváros belsősége és környékének átnézeti térképe. Budapest 1916 (dalej: AMS, mapy, nr 337).

${ }^{26}$ J. Muk, op. cit., Zimná 65.

${ }^{27}$ O Anne M. Szontagh, sestre lekára Michala Szontágha (1751-1825) pozri bližšie D. Szontagh, op. cit., s. 14.

${ }^{28}$ M. Števík, Majitelia domov, s. 74. 


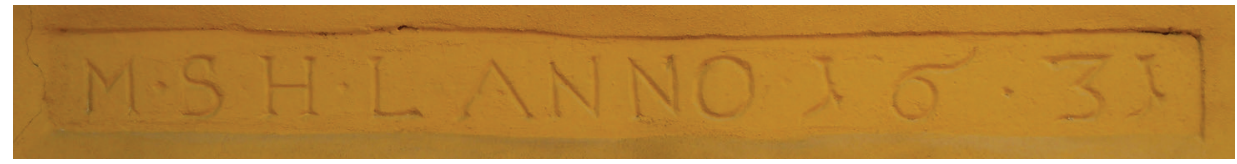

Il. 1. Inskrypcja na kamiennym gzymsie domu przy ul. Letniej 59

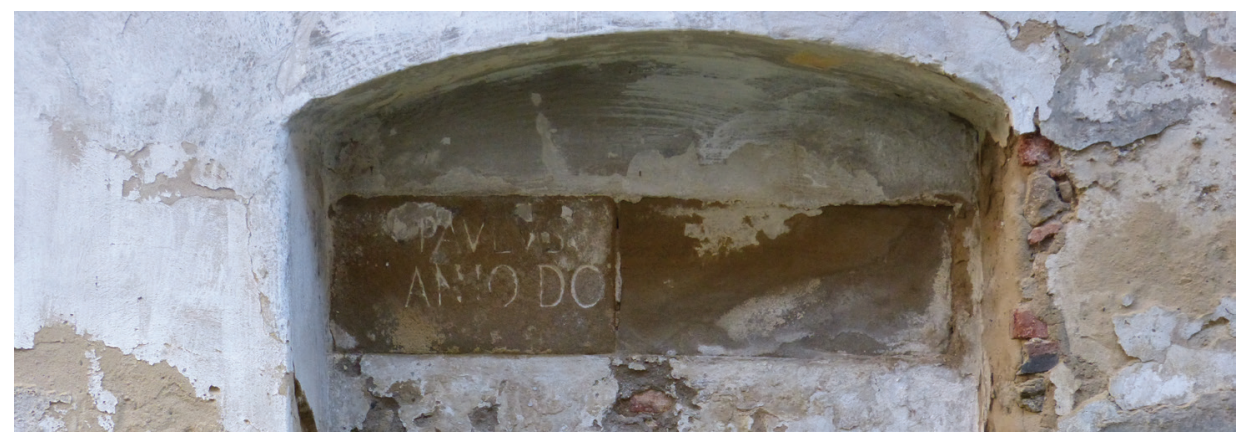

Il. 2. Inskrypcja na kamiennej tablicy domu przy ul. Letniej 34

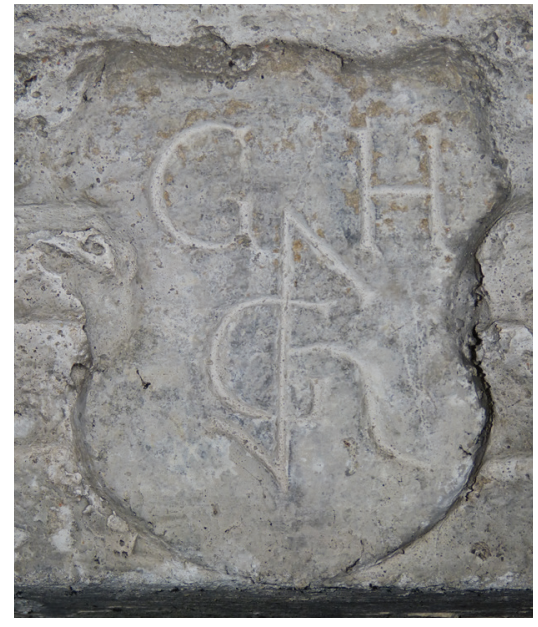

Il. 3. Gmerk budowniczego na renesansowym portalu domu przy ul. Letniej 34

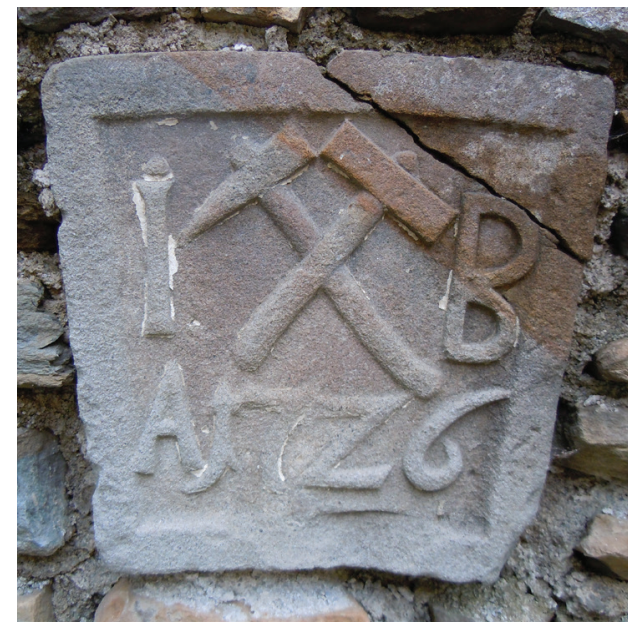

Il. 4. Gmerk mieszczański na kamiennej tablicy domu przy ul. Zimnej 65 


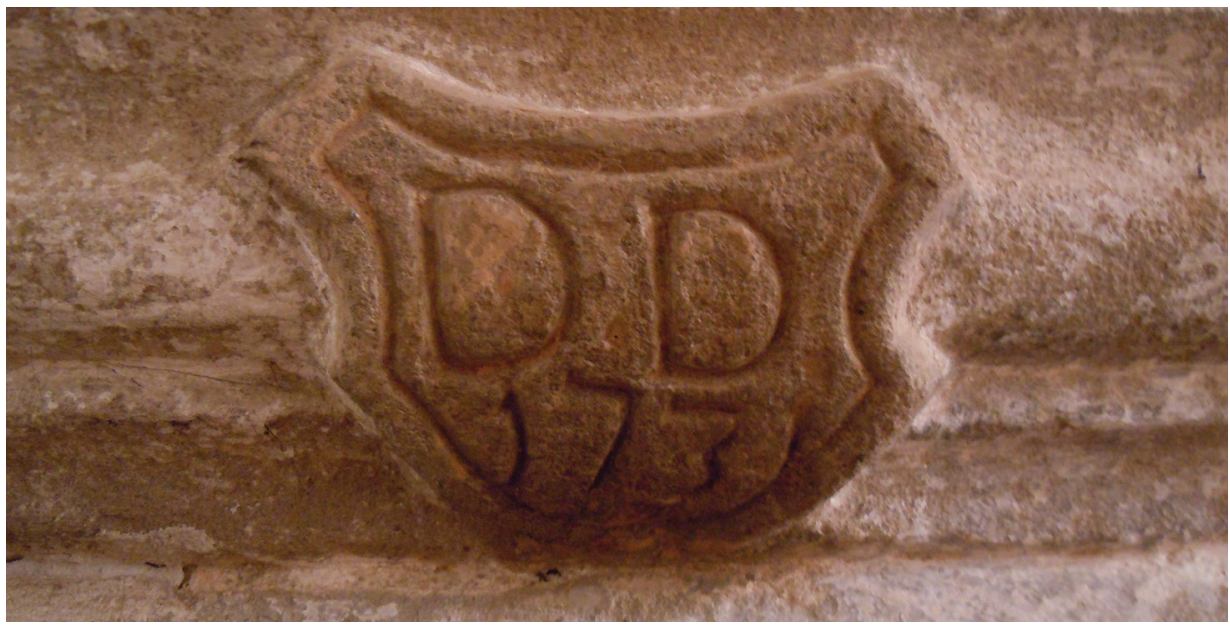

Il. 5. Kamienny mieszczański gmerk na portalu bramy domu przy ul. Letniej 40

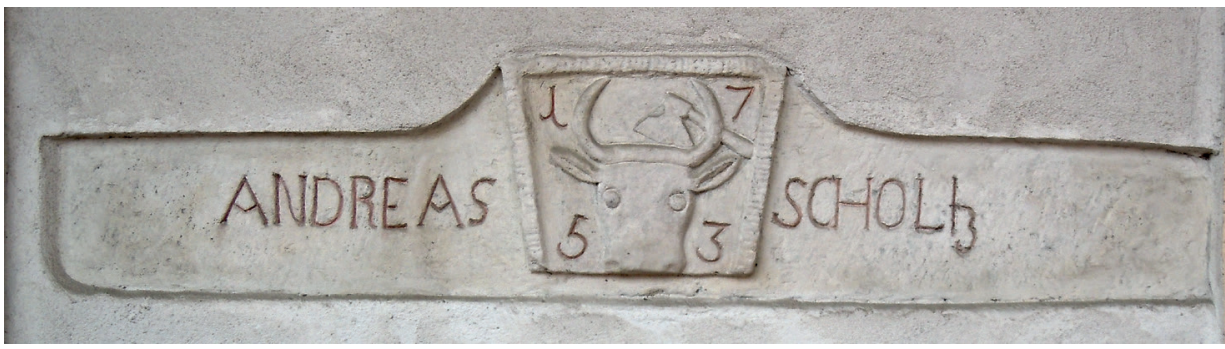

Il. 6. Kamienny mieszczański gmerk wtórnie umieszczony w murze domu przy ul. Letniej 28
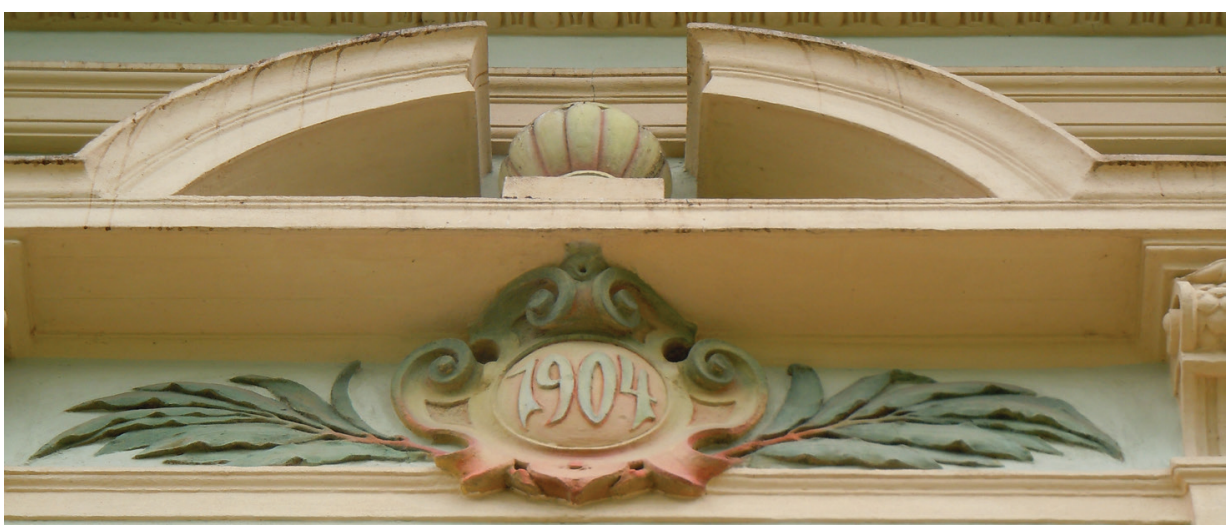

Il. 7. Kartusz z datą przebudowy na frontonie domu przy ul. Letniej 28 


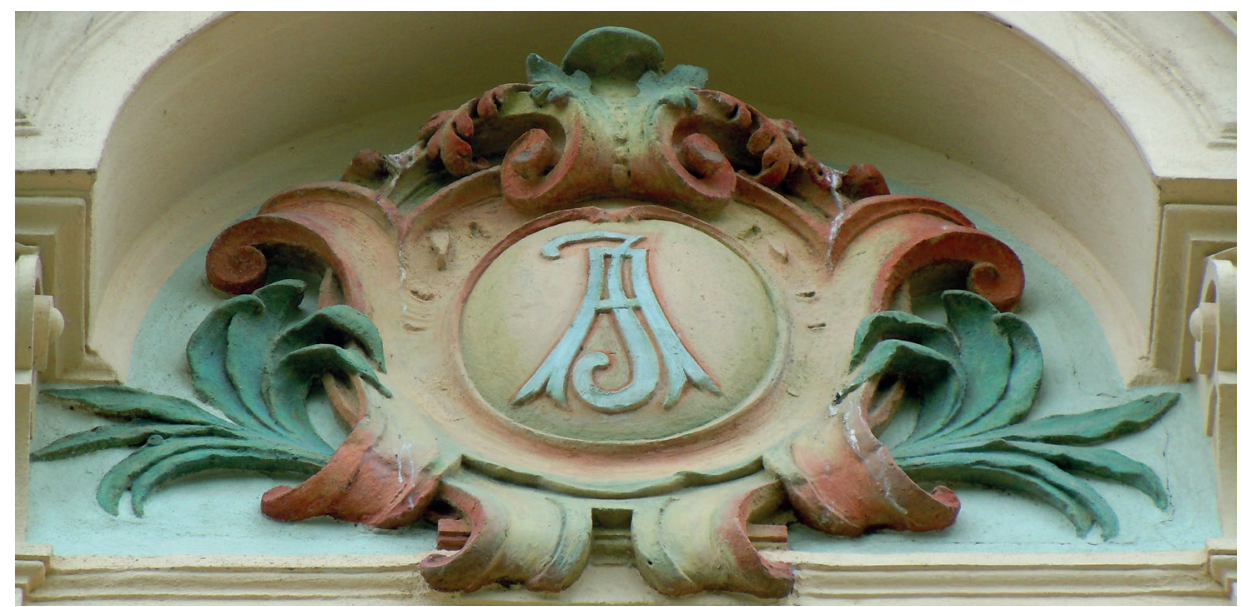

Il. 8. Kartusz z monogramem na domu przy ul. Letniej 28
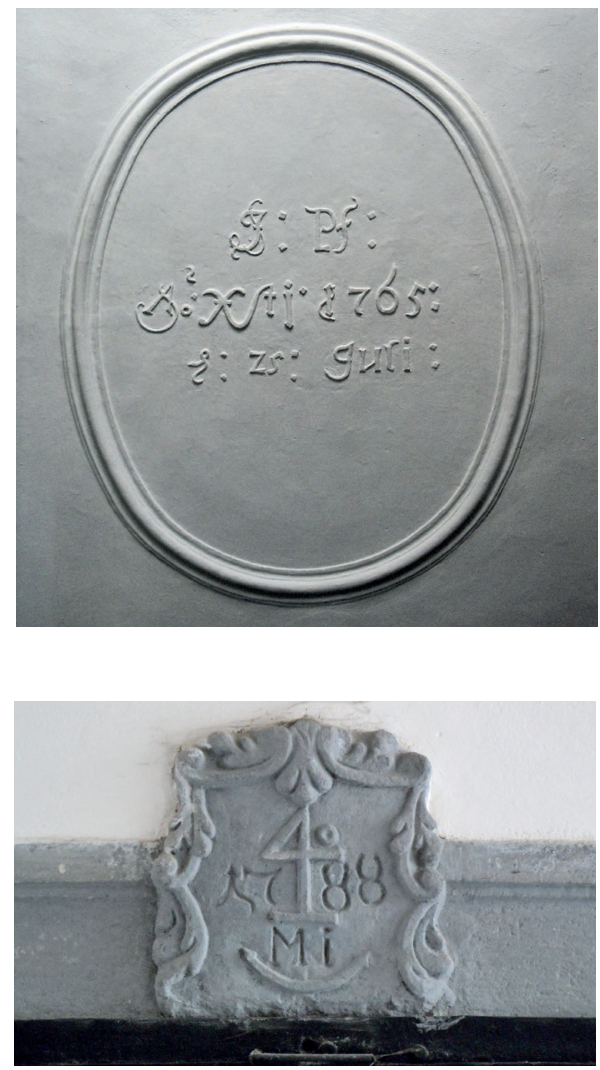

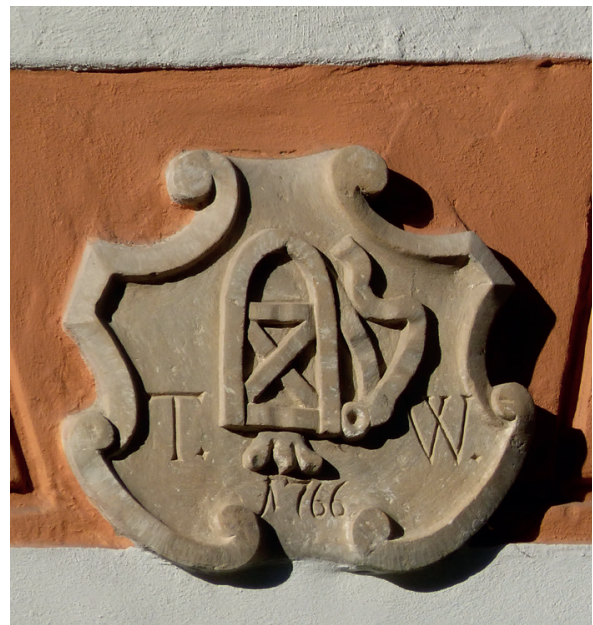

$\leftarrow$ Il. 9. Inskrypcja w polu owalnej dekoracji stiukowej w domu przy ul. Letniej 65

Il. 10. Kamienny mieszczański gmerk nad wejściem do domu przy ul. Zimnej 77

$\leftarrow$ Il. 11. Gmerk budowniczego na klasycystycznym portalu domu przy ul. Letniej 47 


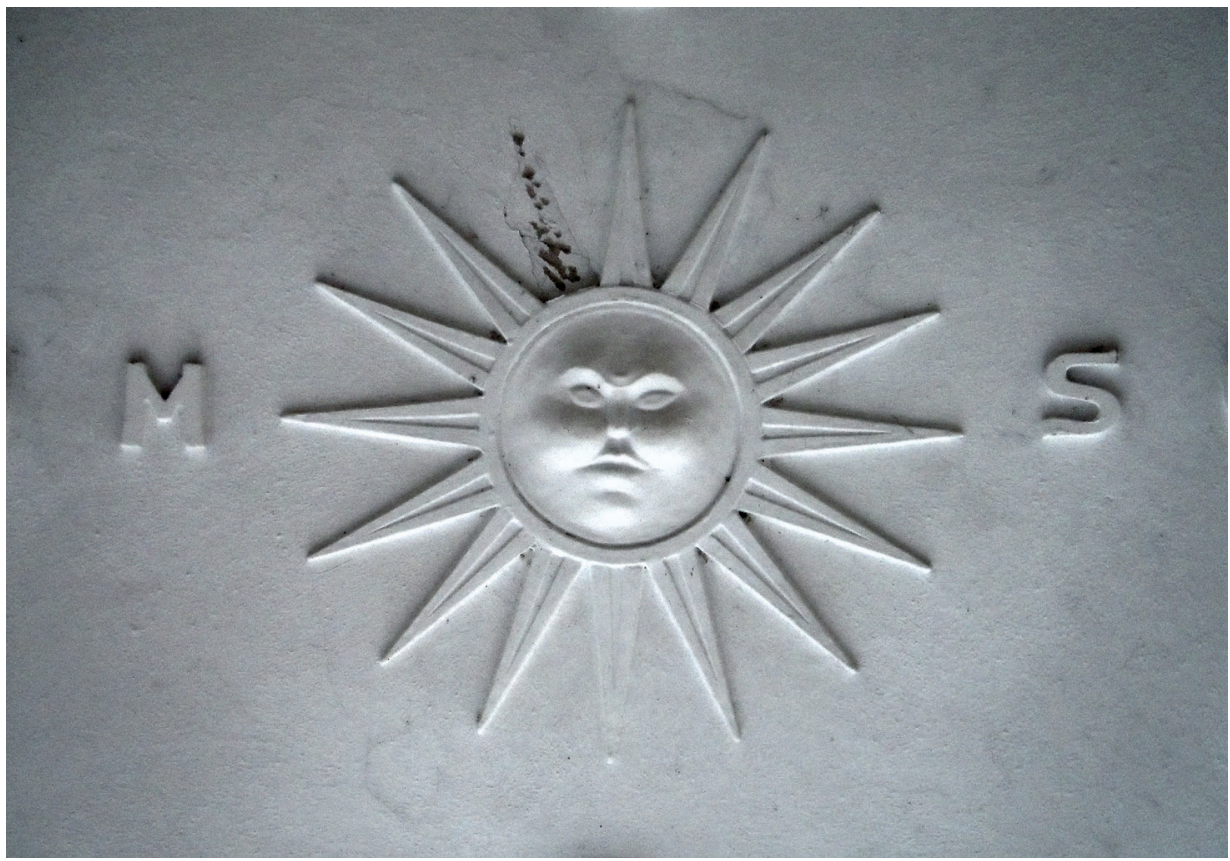

Il. 12. Godło herbu rodu Szontágh w stiukowej dekoracji sklepienia bramy domu przy ul. Letniej 45

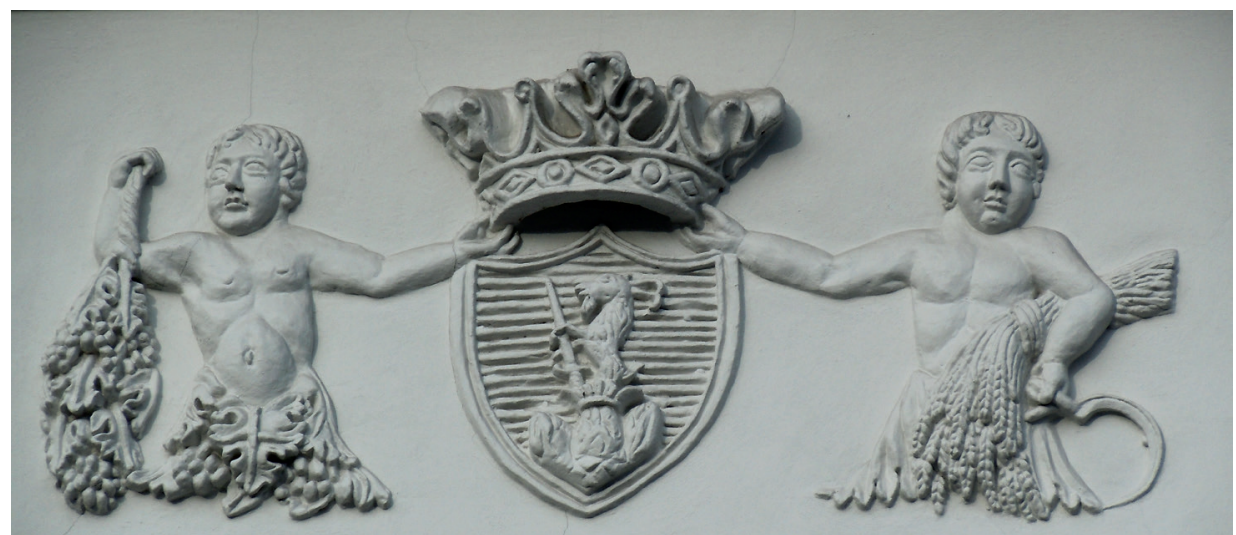

Il. 13. Herb rodu Jóny na stiukowej dekoracji frontonu domu przy ul. Letniej 45 


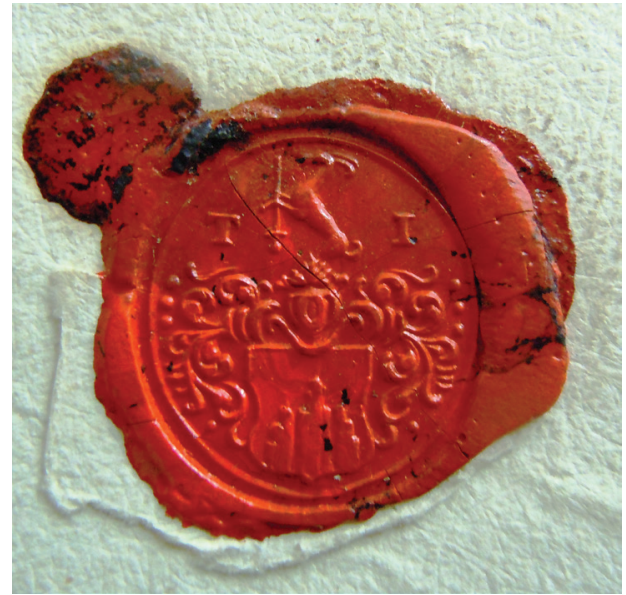

Il. 14. Herb rodu Jóny na pieczęci Tobiásza Jóny $\mathrm{z}$ dokumentu z $1775 \mathrm{r}$.

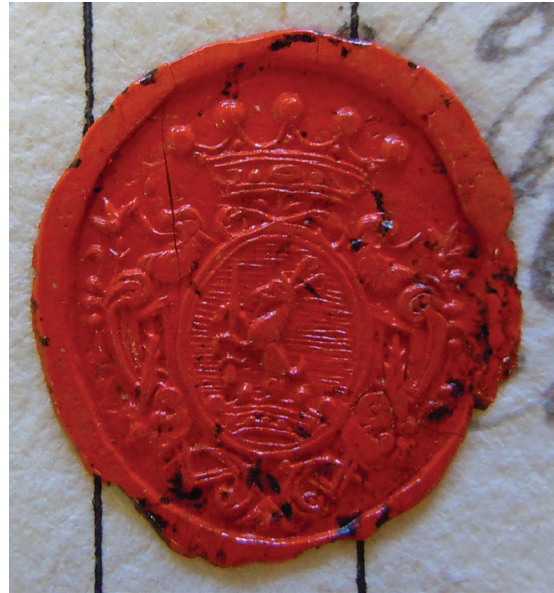

Il. 15. Herb rodu Jóny na pieczęci Jana Baptysty Jóny ze spisu podatkowego Spiskiej Nowej Wsi z ok. 1773 r.

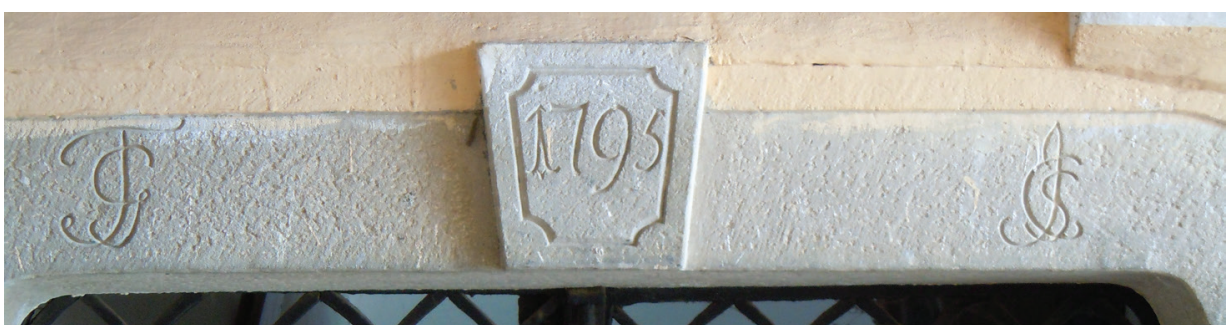

Il. 16. Inskrypcja na klasycystycznym portalu bramy domu przy ul. Letniej 51

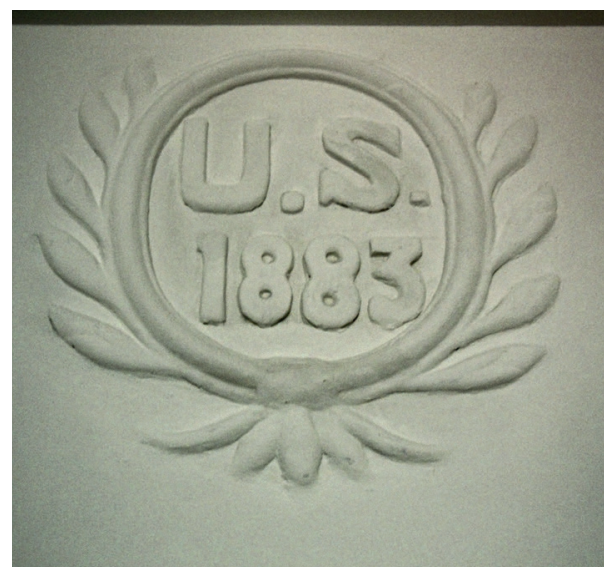

Il. 17. Inskrypcja w kartuszu w domu przy ul. Letniej 27 
upozornil na skutočnost', že v roku 1726 vypukol v Spišskej Novej Vsi obrovský požiar, ktorý - okrem iného - zachvátil 163 domov $^{29}$.

\section{6 (Zimná 44)}

Podla záznamu J. Muka z roku 1981 sa v prejazde domu na Zimnej 44 nachádzal fragment štukového terča vo vrchole s porušeným letopočtom $1826(\text { ? })^{30}$. Súpis pamiatok z roku 1969 uvádza, že renesančný dom zo 17. storočia bol barokovo prefasádovaný v roku $1726^{31}$. Znamená to, že ešte $\mathrm{v}$ šest'desiatych rokoch 20. storočia bol letopočet na štukovom terči čitatelný. Počas návštevy spomínaného prejazdu sa nám už nepodarilo nájste žiaden náznak existencie štukového terča. Každopádne, spomínaný dom vlastnil v rokoch 1773-1777 medikováč Samuel Thoman, v roku 1783 jeho vdova (Vid. Toman) a v roku 1800 Martin Thoman ${ }^{32}$. Je vel'mi pravdepodobné, že to bol príslušník rodu Thoman, ktorý inicioval prestavbu domu po požiari v roku 1726 a záznam o tejto prestavbe dal vyhotovit v prejazde objektu vo forme štukového terča. Pravdepodobne sa tam nachádzali i iniciály jeho mena.

\section{1 (Letná 40, il. 5)}

V prejazde stavby gotického pôvodu ${ }^{33}$ sa na portáli vstupu do pivničných priestorov zachoval meštiansky znak s iniciálami $D D$ a letopočtom $1731^{34}$. Jan Muk upozornil na skutočnost', že portál bol vyhotovený ešte $\mathrm{v}$ obvyklej forme renesančného charakteru ${ }^{35}$. Svedčí to o pretrvávaní renesančného slohu v mestskom prostredí na Spiši ešte aj v prvých desatročiach 18. storočia. V tomto dome býval v rokoch 1773-1784 kožušník Daniel Demian, v roku 1800 vdova po Tobiášovi Demianovi ${ }^{36}$. Z uvedeného je zrejmé, že dom dal prestavat v roku 1731 Daniel Demian, s najväčšou pravdepodobnostou otec spomínaného majitela $\mathrm{z}$ rokov 1773-1784. Datovanie prestavby naznačuje, že sa uskutočnila v dôsledku velkého požiaru mesta v roku $1726^{37}$.

\footnotetext{
${ }^{29}$ J. Muk, op. cit., Letná 40; S. Münnich, Igló királyi korona - és bányaváros története, Igló 1896, s. 300

${ }^{30}$ J. Muk, op. cit., Zimná 44.

31 A. Güntherová, op. cit., s. 151.

${ }^{32}$ M. Števík, Majitelia domov, s. 86.

${ }_{33}$ J. Muk, op. cit., Letná 40.

${ }^{34} \mathrm{Za}$ sprístupnenie domu pre výskum d’akujeme jeho majitelke pani Eve Mesárošovej.

35 J. Muk, op. cit., Letná 40.

${ }_{36}$ M. Števík, Majitelia domov, s. 94.

${ }^{37}$ J. Muk, op. cit., Letná 40.
} 


\section{8 (Zimná 46)}

$\mathrm{V}$ jednom $\mathrm{z}$ architektonicky najhodnotnejších renesančných domov Spišskej Novej Vsi, dnes sídle Galérie umelcov Spiša, sa podla J. Muka v zadnej časti objektu na pilieri nachádzal rok 1748 , ktorý dokumentoval jej výstavbu ${ }^{38}$. Napriek snahám o potvrdenie tohto údaju sa nám ho nepodarilo nájste. V roku 1773 vlastnila dom vdova po šlachticovi Jánovi Jónym (1695-1755) Dorotha Szotágh ${ }^{39}$ $\left(1707^{40}\right.$ - okolo roku 1773), v rokoch 1774-1777 Joannes Baptista Johny ${ }^{41}\left(1733^{42}\right.$ - okolo roku 1783), v roku 1783 vdova Jána Baptistu Johnyho ${ }^{43}$ - Anna Mária Okolicsányi ${ }^{44}$, v roku 1800 Emerich von Jony ${ }^{45}$ (1784-1830), syn Jána Jónyho a Anny Márie Okolicsányi ${ }^{46}$. Z uvedeného prehladu je zrejmé, že výstavbu zadnej (barokovej) časti domu inicioval v roku 1748 Joannes Jóny (1695-1755).

\section{3 (Letná 28)}

Objekt na Letnej 28 obsahuje dva záznamy o stavebných úpravách. Prvý pochádza z roku 1753, druhý z roku 1904 . V dvorovej časti (na stene krídla) sa nachádza meštiansky znak s menom Andreas Scholtz, datovaním 1753 (il. 6), uprostred ktorého je situovaný mäsiarsky znak - hlava býka a mäsiarska sekera. Jan Muk na základe výskumu polohy pivníc upozornil na skutočnost', že pôvodný dom mal prejazd na pravej strane a krídlo vlavo ${ }^{47}$. Zásadným argumentom $\mathrm{v}$ tomto smere je ale podoba pôdorysu tohto objektu na pláne mesta $\mathrm{z}$ roku 1869, podla ktorého pôvodná dispozícia domu ešte vtedy nebola zmenená ${ }^{48}$. Tabula z roku 1753 sa nachádza v krídlovej časti objektu, ktorá v roku 1869 nestála. Umiestnená tu bola sekundárne, a teda nemusela mat nič spoločné s prestavbou predmetného objektu na Letnej 28.

$\mathrm{Na}$ druhej strane podla súpisov z rokov 1773-1783 býval mäsiar Andrej Scholtz v dome na Zimnom riadku č. 310 (dnes č. 63) ${ }^{49}$. Mäsiar s týmto menom

\footnotetext{
38 Ibidem, Zimná 46.

39 M. Števík, Majitelia domov, s. 86.

40 D. Szontagh, op. cit., s. 18; M. Szluha, op. cit., s. 170.

${ }^{41}$ M. Števík, Majitelia domov, s. 86.

${ }^{42}$ M. Szluha, op. cit., s. 170.

43 M. Števík, Majitelia domov, s. 86.

${ }_{44}$ M. Szluha, op. cit., s. 170.

45 M. Števík, Majitelia domov, s. 86.

46 M. Szluha, op. cit., s. 170-171.

47 J. Muk, op. cit., Letná 28.

48 AG, podklad 1, SNV 1869.

49 M. Števík, Majitelia domov, s. 116.
} 
sa v roku 1775 spomína ako podnájomník v dome Andreja Sontága na Zimnom riadku č. 8 (dnes č. 49). V roku 1800 tento dom vlastnila vdova po Andrejovi Scholtzovi ${ }^{50}$. Je možné, že spomínaná tabula z roku 1753 v skutočnosti dokumentovala prestavbu domu mäsiara Andreja Scholtza na Zimnom riadku č. 63 a v dvorovej časti domu na Letnej 28 bola v 20. storočí umiestnená sekundárne. Pokial ide o dom na Letnej 28 , ten bol prestavaný na začiatku 20. storočia, o čom svedčia údaje v kartušiach umiestnených na priečelí budovy. Kartuša nad balkónom obsahuje rok 1904 (il. 7), kartuše nad oknami monogram A. J. Podla Ivana Chalupeckého bol v tom čase majitelom domu Armand Jantner ${ }^{51}$ (il. 8).

\section{5 (Letná 65)}

$\mathrm{V}$ dome na Letnej 65 , ktorý má neskorogotický, resp. renesančný pôvod ${ }^{52} \mathrm{sa}$ na klenbe v štukovom oválnom poli zachoval nápis J. Pf. A. ti. 1765. d. 25. Juli ${ }^{53}$ (il. 9). Predmetný objekt vlastnil v rokoch 1773-1777 kožušník Jacob Pfanschmiedt. Znamená to, že nápis obsahuje meno iniciátora barokovej prestavby domu ${ }^{54}$, ako aj jej datovanie: J(acob). Pf(anschmied). A(nno). (Chris)ti. 1765. d(en). 25. Juli. Podla J. Muka ide o jedinú presne datovanú neckovú klenbu v Spišskej Novej Vsi ${ }^{55}$. Šlachtic Jacob Pfanschmiedt sa narodil v Spišskej Novej Vsi v roku 1727 a jeho manželkou bola Anna Engel ${ }^{56}$.

\section{6 (Zimná 77, il. 10)}

Na vstupnom portáli do domu neskorogotického, resp. renesančného pôvo$\mathrm{du}^{57}$ na Zimnej 77 sa nachádza meštiansky znak s monogramom $T$. W., datovaný rokom 1766 a obsahujúci symbol remenárov ${ }^{58}$. Tento dom vlastnila $\mathrm{v}$ poslednej tretine 18. storočia šlachtická rodina $W i n d t^{59}$. V roku 1773 vystupuje ako majitelka objektu vdova po Jánovi Windtovi (Vidua Windt; Vid. Joan Vindt) ${ }^{60}$

${ }^{50}$ Ibidem, s. 84.

${ }^{51}$ Chalupecký I., op. cit., s. 72.

52 J. Muk, op. cit., Letná 65.

${ }^{53}$ Za prepis nápisu dakujeme docentovi Jurajovi Šedivému z Univerzity Komenského v Bratislave.

${ }^{54}$ Súpis pamiatok charakterizuje objekt ako barokový dom na staršom základe (A. Güntherová, op. cit., s. 153).

${ }_{55}$ J. Muk, op. cit., Letná 65.

${ }^{56}$ M. Szluha, op. cit., s. 308.

${ }^{57}$ J. Muk, op. cit., Zimná 77.

${ }^{58}$ M. Števík, Majitelia domov, s. 110.

${ }^{59}$ Ibidem.

${ }^{60}$ Ibidem. 
- Mária, ${ }^{61}$ v rokoch 1774-1784 doložený ako majitel Thobias Windt ${ }^{62}$, syn Jána $(1707-?)^{63}$ a Márie Windtovcov ${ }^{64}$, v roku 1800 vdova Tobiáša Windta (Vid. Thobias Windt) ${ }^{65}$ - Zuzana. ${ }^{66}$ Znamená to, že barokovú prestavbu ${ }^{67} \mathrm{v}$ roku 1766 inicioval šlachtic, remenár Thobias Windt ${ }^{68}$, ktorý sa v Spišskej Novej Vsi narodil $\mathrm{v}$ roku $1739^{69}$ a zomrel $\mathrm{v}$ závere 18. storočia (po roku 1784, resp. pred rokom 1800). Menší požiar v Spišskej Novej Vsi, ktorý zachvátil 13 domov, vypukol v roku $1766^{70}$, no jeho súvis s prestavbou domu Windtovcov nie je preukázaný.

\section{8 (Letná 47)}

$\mathrm{V}$ prejazde pôvodne gotického domu na Letnej $47^{71}$ sa na klasicistickom portáli zachoval znak stavebníka s iniciálami $M i$ a rokom $1788^{72}$ (il. 11). V poslednej tretine 18. storočia vlastnila dom rodina Köhler, konkrétne v rokoch 1773-1784 je doložený ako vlastník Samuel Kőhler, v roku 1800 jeho vdova (Vid. Samuel Kőhler). Z uvedeného vyplýva, že klasicistickú prestavbu ${ }^{73}$ domu v roku 1788 iniciovala rodina Kőhler. Realizátor prestavby - murársky majster s iniciálami M I zvečnil prácu na tomto dome v roku 1788 prostredníctvom svojho znaku na klasicistickom portáli v prejazde.

\section{7. a 18. storočie (Letná 45)}

Z pohladu heraldiky najpozoruhodnejším domom námestia v Spišskej Novej Vsi je objekt na Letnej 50. Tento pôvodne neskorogotický dom, prestavaný v období renesancie ${ }^{74}$, obsahuje $\mathrm{v}$ prejazde štukovú výzdobu s ústredným motívom erbu rodiny Szontágh - slnkom. Hned’ vo vstupe sa v hornej časti renesančnej

${ }^{61}$ M. Szluha, op. cit., s. 433.

${ }^{62}$ M. Števík, Majitelia domov, s. 110.

${ }^{63}$ Ján Windt zomrel pred rokom 1766, kedže prestavbu domu realizoval jeho syn Tobiáš.

${ }^{64}$ M. Szluha, op. cit., s. 433.

${ }^{65}$ M. Števík, Majitelia domov, s. 110.

${ }^{66}$ M. Szluha, op. cit., s. 433.

${ }^{67}$ A. Güntherová, op. cit., s. 152. Súpis pamiatok charakterizuje objekt ako renesančno-barokový.

${ }^{68}$ M. Števík, Majitelia domov, s. 110. Tobiáš Windt je v súpise z roku 1773 zapísaný ako remenár.

${ }^{69}$ M. Szluha, op. cit., s. 433.

${ }^{70}$ S. Münnich, op. cit., s. 343.

${ }^{71}$ J. Muk, op. cit., Letná 47.

${ }^{72}$ M. Števík, Majitelia domov, s. 98.

${ }^{73}$ Súpis pamiatok charakterizuje fasádu domu ako klasicistickú z 2. polovice 18. storočia (A. Güntherová, op. cit., s. 152).

${ }^{74}$ J. Muk, op. cit., Letná 45. 
klenby ${ }^{75}$ nachádza štuková výzdoba zobrazujúca slnko a iniciály $M S$ (il. 12). Motív slnka ako súčast štukovej výzdoby sa vyskytuje po oboch stranách prejazdu na viacerých miestach. Zobrazenie slnka v podobe tváre (s očami, nosom, lícami a ústami) na klenbe prejazdu plne korešponduje s ústredným motívom erbu rodiny Szontágh ${ }^{76}$. Po oboch stranách slnka na štukovej výzdobe sa nachádzajú písmená M S(zontágh), ktoré možno stotožnit’s príslušníkom rodu Szontágh - iniciátorom renesančnej prestavby objektu v 17. storočí ${ }^{77}$. V poslednej tretine 18. storočia bol dom vo vlastníctve rodiny Jóny. V rokoch 1773-1784 je ako majitel' doložený Johan Ew. Jony ${ }^{78}$. Podla rozboru genealogickej tabul'ky rodu Jóny, ktorú publikoval Márton Szluha v roku 2013, ide podla všetkého o Jána Jónyho, ktorý sa narodil v roku $1738 \mathrm{v}$ L’ubici $^{79}$. Uvedené konštatovanie podporujú nasledujúce argumenty. Ján Jóny sa v roku 1779 oženil s Klárou Székely ${ }^{80}$. V roku 1800 už ako majitel' domu na Letnej 45 vystupuje Paul Scholtz ${ }^{81}$. Na druhej strane, dom mäsiarskej rodiny Scholtzovcov na Zimnej 310 (Andreas Scholtz doložený ako majitel v rokoch 1773-1784) vlastnila v roku 1800 šlachtičná Clara v. Szekely ${ }^{82}$. Podla daňového súpisu z roku 1824 vystupuje ako majitel' domu na Letnej 45 Imrich Jóny a v predmetnom dome bývala aj Clara Szekely ${ }^{83}$.

Uvedené fakty sú dôležité pre datovanie vzniku erbu rodu Jóny, ktorý sa zachoval na priečelí domu na Letnej 45 (il. 13). Jan Muk o tejto fasáde konštatoval, že je empírová z prvého dvadsatročia 19. storočia ${ }^{84}$. V Súpise pamiatok sa uvádza, že dom bol prefasádovaný a upravený koncom 18 . storočia ${ }^{85}$. Na základe analógií s inými stavbami s empírovými fasádami pokladáme za správnu interpretáciu J. Muka.

Podla záznamu z roku 1696 štít erbu rodu Jóny obsahoval modré trojvršie (tri skalné štíty), klenot tvoril cap vyrastajúci z koruny ${ }^{86}$. Na priečelí domu na

${ }^{75}$ Ibidem.

76 D. Szontagh, op. cit., s. 9.

77 Ako renesančný dom zo 17. storočia je objekt charakterizovaný v Súpise pamiatok (A. Güntherová, op. cit., s. 152).

${ }_{78}^{78}$ M. Števík, Majitelia domov, s. 96.

${ }^{79}$ M. Szluha, op. cit., s. 433.

${ }^{80}$ Ibidem.

${ }^{81}$ M. Števík, Majitelia domov, s. 96.

${ }^{82}$ Ibidem, s. 116.

${ }^{83}$ Spišský archív Levoča (dalej: SaL), Provincia xvi spišských miest, Súpisy a výruby daní, Spišská Nová Ves (dalej: Provincia XVI), i. č. 2338/1824.

${ }^{84}$ J. Muk, op. cit., Letná 45.

${ }^{85}$ A. Güntherová, op. cit., s. 152.

${ }^{86}$ M. Szluha, op. cit., s. 174. 
Letnej 45 erb rodu Jóny zobrazuje v štíte korunované trojvršie (tri skalné štíty), z ktorého vyrastá cap držiaci prednými nohami meč obrátený hrotom nahor. Nad štítom sa nachádza vel'ká koruna. Na pečiatke grófa Provincie XVI spišských miest Tobiáša Jónyho, vlastniaceho v roku 1773 domy na Zimnej č. 304 (dnes 60) a č. 319 (dnes Rožňavská ulica) ${ }^{87}$, ktorú obsahuje jeho prípis z roku $1775^{88}$, štít zobrazuje trojvršie, klenot capa držiaceho prednými nohami meč obrátený hrotom nahor. Po oboch stranách klenotu sú iniciály T(obias) I(ony) (il. 14). Pečat Jána Baptistu Jónyho na súpise daní Spišskej Novej Vsi z obdobia okolo roku $1773^{89}$, vlastniaceho v rokoch 1774-1777 dom na Zimnej $46^{90}$, obsahuje v oválnom štíte capa vyrastajúceho z koruny, ktorý drží prednými nohami meč obrátený hrotom nahor. Nad oválnym štítom sa nachádza vel'ká koruna (il. 15). Zachovaný erb šlachticov z rodu Jóny na priečelí domu Letná 45 sa radí k najcennejším a umelecky najzaujímavejším zobrazeniam šlachtických erbov na priečeliach spišských domov. Iniciátorom vyhotovenia empírovej fasády z prvých dvoch desatročí 19. storočia bol na základe uvedených faktov s najväčšou pravdepodobnostou Imrich Jóny.

\section{5 (Letná 51)}

$\mathrm{Z}$ meštianskych domov spišskonovoveského námestia na jeho slnečnej strane vyniká dom na Letnej 51, ktorý je vôbec najširším domom starého mesta. Vznikol spojením dvoch samostatných domov v závere 18. storočia, čo dokumentuje predovšetkým barokovo-klasicistické členenie priečelia ${ }^{91}$. V prejazde domu v hornej časti klasicistického portálu sa nachádza nápis: TG 1795 JSC (il. 16). V poslednej tretine 18. storočia sú ako majitelia pôvodne väčšieho $\mathrm{z}$ dvoch spojených domov doložení - šlachtičná Sussana Schneider (1773-1784) a šlachtic Thomas von Gerhardt (1800) ${ }^{92}$. Manželkou Tomáša Gerhardta bola Johanna Schneider ${ }^{93}$. Spomínaní manželia iniciovali okolo roku 1795 klasicistickú prestavbu domu, resp. spojenie dvoch susedných objektov. Kované železné zábradlie domu je datované rokom $1793^{94}$. Túto vel'kolepú prestavbu dokumentuje nápis na

\footnotetext{
${ }^{87}$ M. Števík, Majitelia domov, s. 114, 118.

88 Štátny archív Prešov, pracovisko Stará Lubovňa, Archív mesta Hniezdne, listiny, 7/1775.

${ }^{89}$ Provincia XVI, i. č. 985 b. r.; sign. 1044. Tento súpis, v Spišskom archíve v Levoči vedený ako nedatovaný a neidentifikovaný, bol vyhotovený okolo roku 1773 (M. Števík, Majitelia domov, s. 77).

90 M. Števík, Majitelia domov, s. 86.

91 J. Muk, op. cit., Letná 51.

92 M. Števík, Majitelia domov, s. 100.

93 M. Szluha, op. cit., s. 250.

94 A. Güntherová, op. cit., s. 152.
} 
klasicistickom portáli v prejazde: T(homas) G(erhardt) 1795 J(ohanna) SC(hneider $)^{95}$. Za pozornost' ešte stojí skutočnost', že rodine Schneider, do ktorej sa priženil Thomas von Gerhardt, patril aj dom na Letnej 42. Majitelom predmetného objektu bol v roku 1783 Thomas Gerhardt ${ }^{96}$. Ked’ sa dcéra Tomáša Gerhardta a Jany Schneider - Kristína Gerhardt (1774-1839) v roku 1799 vydala za Františka Máriássyho (1770-1851) ${ }^{97}$, tento dom sa dostal do jeho vlastníctva (Francz von Maryassy, 1800) ${ }^{98}$. Znamená to, že druhý dom Schneiderovcov (na Letnej 42) plnil úlohu akéhosi „údelu“ pre tých, ktorí sa priženili do rodiny. Rovnako dom na Letnej 42 vznikol spojením dvoch samostatných domov. Jan Muk vyjadril predpoklad, že sa tak udialo $\mathrm{v}$ šesṫdesiatych až sedemdesiatych rokoch 18 . storočia ${ }^{99}$. V roku 1773 je už tento dom uvádzaný pod jedným číslom ${ }^{100}$, z čoho vyplýva, že spojenie dvoch objektov sa uskutočnilo pred rokom 1773, v čase, ked' tento dom bol v majetku šlachtica Sigmunda Schneidera (vlastníctvo doložené ešte v rokoch 1773-1777) ${ }^{101}$. Súpis pamiatok charakterizuje objekt ako neskorobarokový z obdobia okolo rokov $1770-1780^{102}$, J. Muk ako budovu palácového charakteru so šestosovým, bohato členeným priečelím neskorobarokového charakteru $^{103}$. Znamená to, že k prestavbe objektu, resp. spojeniu dvoch susedných domov došlo okolo roku 1770, nesporne pred rokom 1773, každopádne v čase, ked' bol jeho majitelom Sigmund Schneider, ktorého možno označit za iniciátora neskorobarokovej prestavby domu na Letnej 42.

\section{3 (Letná 27)}

$\mathrm{Na}$ poschodí domu na Letnej 27 sa zachovala kartuša $s$ iniciálami U. S. $1883^{104}$. Jan Muk vyslovil predpoklad, že spomínané datovanie súvisí s prestavbou spájajúcou pôvodné dva domy do jedného objektu. Jeho priečelie charakterizoval ako neorenesančné z roku $1883^{105}$. Súpis pamiatok na druhej strane

\footnotetext{
${ }_{95}$ M. Števík, Provinčnýdom, s. 8.

${ }^{96}$ M. Števík, Majitelia domov, s. 96.

${ }^{97}$ M. Szluha, op. cit., s. 250.

${ }_{98}$ M. Števík, Majitelia domov, s. 96.

${ }^{99}$ J. Muk, op. cit., Letná 42.

${ }^{100}$ M. Števík, Majitelia domov, s. 96.

${ }^{101}$ Ibidem.

102 A. Güntherová, op. cit., s. 152.

${ }^{103}$ J. Muk, op. cit., Letná 27.

${ }^{104} \mathrm{Za}$ upozornenie na uvedenú skutočnosṫ dakujeme Pharm Dr. Žofii Kellnerovej.

${ }^{105}$ J. Muk, op. cit., Letná 27.
} 
uvádza, že dom bol prefasádovaný v 18. storočí1 ${ }^{106}$. Porovnanie máp mesta z rokov $1869^{107}$ a $1914^{108}$ dokazuje, že k spojeniu oboch domov došlo až po roku 1869 , resp. pred rokom 1914. Znamená to, že fasáda nemôže byṫ z 18. storočia, ako sa uvádza v Súpise pamiatok ${ }^{109}$. Pravdu mal Jan Muk, ktorý správne zadatoval priečelie, ako aj prestavbu domu do obdobia konca 19. storočia $(1883)^{110}$. Pokial ide o iniciály $U S$, archívny výskum naznačuje, že prestavbu z roku 1883 bude potrebné spojit’ s príslušníkom rodiny Újházy. $\mathrm{K}$ tomuto konštatovaniu nás vedie fakt, že v roku 1843 vlastnila lavú čast̉ dnešného domu na Letnej 27 vdova po Jánovi Ujházym ( $V$. Joh. Uihaszy) ${ }^{111}$. K popredným meštanom Spišskej Novej Vsi posledných desatročí 19. storočia patril Samu Ujházy, spomínaný v Münnichových dejinách mesta $\mathrm{v}$ rokoch 1874 a $1881^{112}$. Znamenalo by to, že uvedený nápis v kartuši by sa mal čítat ako U(jházy) S(amu) 1883 (il. 17). Kedže výskum majitelov domov Spišskej Novej Vsi 19. storočia je naplánovaný na rok 2018, uvedený predpoklad bude ešte predmetom overenia.

\section{Zhrnutie}

Cielom štúdie bolo poukázat na význam využitia poznatkov z viacerých vedných odborov, ktoré môžu významným spôsobom obohatit naše poznanie, $\mathrm{v}$ tomto prípade $\mathrm{z}$ oblasti histórie, dejín umenia, genealógie, epigrafiky či heraldiky v súvislosti s výskumom domov historického centra Spišskej Novej Vsi. Tromi piliermi tejto štúdie sa stali poznatky zo stavebno-historických výskumov (Súpis pamiatok z roku 1969 a práca Jana Muka z roku 1981), z genealogického výskumu (Márton Szluha, 2013) a výskumu majitelov domov z rokov 1773-1800 (Miroslav Števík, 2016). Na základe uvedených poznatkov sa podarilo bližšie určit pôvod a obsah viacerých heraldických a epigrafických pamiatok domov Spišskej Novej Vsi. Tieto vznikali v rozličných obdobiach, spravidla pri významnejších prestavbách. Najčastejšie ich nachádzame v horných častiach portálov v prejazdoch domov (Letná 40, Letná 47, Letná 51), nad vstupmi z ulice do domov (Zimná 77), na priečelí domu (Letná 28), v dvorovej časti (Letná 28, Letná 34, Letná 59), na pilieroch (Zimná 46), resp. v štukovej podobe na klenbách izieb

\footnotetext{
106 A. Güntherová, op. cit., s. 152.

107 AG, podklad 1, SNV 1869.

108 AMS, mapy, nr $337 \mathrm{H}$.

${ }^{109}$ A. Güntherová, op. cit., s. 152.

${ }^{110}$ J. Muk, op. cit., Letná 27.

${ }^{111}$ Provincia XVI, kart. 1044.

112 S. Münnich, op. cit., s. 544 .
} 
(Letná 65) či chodieb, v prejazdoch (Zimná 44), resp. v schodiskových častiach (Letná 27). V súčasnosti sa niektoré epigrafické pamiatky nachádzajú v sekundárnej polohe (Zimná 65, Letná 28). Tieto pamiatky spravidla obsahujú iniciály iniciátorov prestavieb predmetných objektov (majitelov domov) a letopočet, kedy sa uskutočnili. Na troch meštianskych znakoch sa zachovali symboly profesie majitelov (remenár Windt - Zimná 77, tažiar Benigni - Zimná 65, mäsiar Scholtz - Letná 28). V dvoch prípadoch sa podarilo určit znaky stavebníkov - realizátorov prestavieb, resp. murárskych majstrov, ktoré boli umiestnené na portáloch (Letná 47, Letná 34). Z pohladu datovania prestavieb domov stojí za pozornost' skutočnost', že sa epigrafické pamiatky koncentrujú $\mathrm{v}$ určitých časových obdobiach - 1631, 1640, 1671; 1726, 1726, 1731; 1748, 1753 ${ }^{113} ; 1765,1766 ; 1788,1795$; 1883. Prinajmenšom požiar v roku 1726 , jeden vôbec $\mathrm{z}$ najväčších v dejinách mesta, sa stal podnetom na obnovu zničených domov.

Z pohladu heraldiky vystupuje ako najzaujímavejší dom v Spišskej Novej Vsi objekt na Letnej 45 , kde sa $\mathrm{v}$ prejazde $\mathrm{v}$ podobe štukovej výzdoby zachoval hlavný motív erbu šlachtickej rodiny Szontágh (17. storočie) a na priečelí erb rodu Jóny (prvé dve desatročia 19. storočia).

Z hladiska určenia iniciátorov prestavieb domov výskum priniesol nové poznatky - s výnimkou dvoch nápisov zo 17. storočia - v prípade všetkých vyššie uvedených objektov. Pravdepodobne sa určila baroková prestavba domu na Zimnej 63 (1753), spresnilo sa datovanie neskorobarokovej prestavby domu na Letnej 42 (okolo roku 1770, resp. pred rokom 1773) a prestavby (spojenia dvoch objektov) domu na Zimnej 65 (po roku 1869, resp. pred rokom 1914).

$\mathrm{Z}$ pohladu genealógie výskum priniesol početné nové údaje biografického charakteru, resp. údaje týkajúce sa mien majitelov domov. Uved'me príklad. V genealogickej tabul'ke šlachtickej rodiny Jóny vystupujú v 18. storočí, okrem iných, dvaja Jánovia - Ján narodený v Lubici v roku 1733 a Ján narodený v Lubici v roku $1738^{114}$. Prvý z menovaných vlastnil v rokoch 1774-1777 dom na Zimnej 46. V súpisoch sa uvádza aj ako Joannes Baptista Jóhny ${ }^{115}$. Druhý z menovaných vlastnil v rokoch 1773-1784 dom na Letnej 45 a súpisy ho zaznamenávajú aj v podobe Johan Ew.(angelista) Jony ${ }^{116}$.

${ }^{113}$ Niektoré z dnes už neexistujúcich domov historickej zástavby obsahovali vročenia 1743 , 1754 (A. Güntherová, op. cit., 151-152).

${ }^{114}$ M. Szluha, op. cit., s. 170-171.

${ }^{115}$ M. Števík, Majitelia domov, s. 86.

${ }^{116}$ Ibidem, s. 96. 
Z hladiska epigrafiky sa podarilo pri väčšine nápisov určit mená majitelov domov, resp. iniciátorov prestavieb, čo dokladá nasledujúca tabul'ka.

Tab. 1. Nápisy domov historického centra Spišskej Novej Vsi z rokov 1631-1904

\begin{tabular}{|l|l|l|}
\hline \multicolumn{1}{|c|}{ Ulica, číslo } & \multicolumn{1}{|c|}{ Nápis } & \multicolumn{1}{c|}{ Meno a priezvisko } \\
\hline Letná 59 & M.S H.L ANNO 16.31 & $?$ \\
\hline Letná 34 & $\begin{array}{l}\text { PAVLVS (?) } \\
\text { ANNO DO(MINI) (1640 ?) }\end{array}$ & $?$ \\
\hline Letná 33 & RENOVATVM 1671 & (Grünblath) \\
\hline Zimná 65 & $\begin{array}{l}\text { I(oannes) B(enigni) } \\
\text { A(nno) 1726 }\end{array}$ & Ioannes Benigni \\
\hline Letná 40 & D(aniel) D(emian) 1731 & Daniel Demian \\
\hline $\begin{array}{l}\text { Zimná 63? } \\
\text { (sekundárne Letná 28) }\end{array}$ & Andreas Scholtz 1753 & Andreas Scholtz \\
\hline Letná 65 & $\begin{array}{l}\text { J(acob): Pf(anschmied): A(nno). (Chris)ti. } \\
1765: \text { d(en): } 25: \text { Juli: }\end{array}$ & Jacob Pfanschmied \\
\hline Zimná 77 & T.(obias W.(indt) 1766 & Tobias Windt \\
\hline Letná 51 & $\begin{array}{l}\text { T(homas) G(erhardt) 1795 } \\
\text { J(ohanna) SC(hneider) }\end{array}$ & $\begin{array}{l}\text { Thomas von Gerhardt } \\
\text { Johanna Schneider }\end{array}$ \\
\hline Letná 27 & U.(jházy) S(amu). 1883 & Ujházy Samu \\
\hline Letná 28 & A. J. 1904 & Armand Jantner \\
\hline
\end{tabular}

\section{Summary}

\section{Heraldic and epigraphic memorials of the houses in Spišská Nová Ves and their source value when identifying their owners}

The author of the paper attempted to identify the heraldic and epigraphic memorials of the houses in the historical center of Spišská Nová Ves, which originated from the $17^{\text {th }}$ century until the beginning of the $20^{\text {th }}$ century. This attempt is based on the comparison of the results of his own archival research of the owners of the houses in the historical center of Spišská Nová Ves in the $18^{\text {th }}$ and $19^{\text {th }}$ centuries, with the construction and historical research of Jan Muk (1981) and the genealogical research of Márton Szluha of the nobility at Spiš (2013). 
KEYWORDS: Slovakia, Spišs, Spišská Nová Ves, $17^{\text {th }}-20^{\text {th }}$ century, epigraphy, heraldry, owners of burgher houses.

\section{Bibliografia}

Chalupecký I., Spišská Nová Ves a okolie, Košice 1971.

Janovská M., Krempaská Z., Provinčný dom v Spišskej Novej Vsi. História - architektúra - múzeum, Spišská Nová Ves 2016.

Münnich S., Igló királyi korona - és bányaváros története, Igló 1896.

Števík M., Geometrický plán vnútorných pozemkových majetkov Spišskej Novej Vsi z roku 1783 (Príspevok k počiatkom Provincie XVI spišských miest), „Spiš. Vlastivedný zborník", t. 6, 2014, s. 73-101.

Števík M., Majitelia domov historického centra Spišskej Novej Vsi v poslednej tretine 18. storočia, „Spiš. Vlastivedný zborník”, t. 8, 2016, s. 72-119.

Števík M., Provinčný dom v Spišskej Novej Vsi a Provincia XVI spišských miest, Spišská Nová Ves 2016.

Súpis pamiatok na Slovensku, t. 3, red. A. Güntherová, Bratislava 1969.

Szluha M., Szepes vármegye nemes családjai, Budapest 2013.

Szontagh D., Iglói és zabari Szontagh nemzetség származási története és oklevelei, Pest 1864. 